\title{
REPTILES AND AMPHIBIANS
}

\section{THE RANA (RESEARCHING AMPHIBIAN NUMBERS IN ALBERTA) PROJECT}

LISA TAKATS, Alberta Conservation Association, $7^{\text {th }}$ floor, O.S. Longman Building, 6909-116 Street, Edmonton, AB T6H 4P2 (lisa.takats@env.gov.ab.ca)

\section{Introduction}

Declines in amphibian populations are occurring around the world, but some regions, and some species are experiencing more dramatic declines than others. There is no clear pattern yet as to which species are subject to declines and which are not. A great deal more work needs to be done in order to fill gaps in our knowledge in respect to the geography of amphibians, and where declines are occurring. Little information is available on population fluctuations and/or distributional changes for many species of amphibians (Pechmann and Wilbur 1994). ${ }^{3}$

In Alberta, little work had been conducted on amphibians, and no longterm standardized data have been collected. The RANA (Researching Amphibian Numbers in Alberta) project began in 1997. This monitoring program combines intensive monitoring with public education.

The objectives of the program for 1998-99 were:

To institute intensive, standardized monitoring programs at five representative breeding sites in the province of Alberta.
To use these sites as tools to educate the public about the amphibians of Alberta and how studies are conducted.

\section{Methods}

Study Sites

Five sites were surveyed in 1998: Beaverhill Lake, Cypress Hills, Kananaskis, Lesser Slave Lake, and Meanook (Figure 1, Table 1). Beaverhill, Lesser Slave, and Meanook had been surveyed in the summer of 1997 . Sites were chosen based on three criteria: 1 ) must be representative of an ecoregion and encompass a variety of breeding amphibian species, 2) must be close to a park or protected area where the public visit, and 3) must be amenable to having pitfall traps placed around the site. 
Table 1: Latitude, Longitude, and Ecoregion of the five study sites in 1998.

\begin{tabular}{lllll}
\hline Study Site & Ecoregion & Latitude & Longitude & $\begin{array}{l}\text { Pond } \\
\text { Circumference }\end{array}$ \\
\hline Beaverhill Lake & Aspen Parkland & $53.38^{\circ}$ & $112.53^{\circ}$ & $9-10 \mathrm{~m}$ arrays \\
Cypress Hills & Montane/Prairie & $49.66^{\circ}$ & $110.06^{\circ}$ & $140 \mathrm{~m}$ \\
Kananaskis & Montane & $50.95^{\circ}$ & $115.14^{\circ}$ & $90 \mathrm{~m}$ \\
Lesser Slave & Boreal Forest & $55.35^{\circ}$ & $114.74^{\circ}$ & $250 \mathrm{~m}$ \\
$\begin{array}{l}\text { Lake } \\
\text { Meanook }\end{array}$ & Boreal Forest & $54.62^{\circ}$ & $113.35^{\circ}$ & $240 \mathrm{~m}$ \\
\hline
\end{tabular}

Figure 1: Map of 1998 RANA site locations in Alberta.

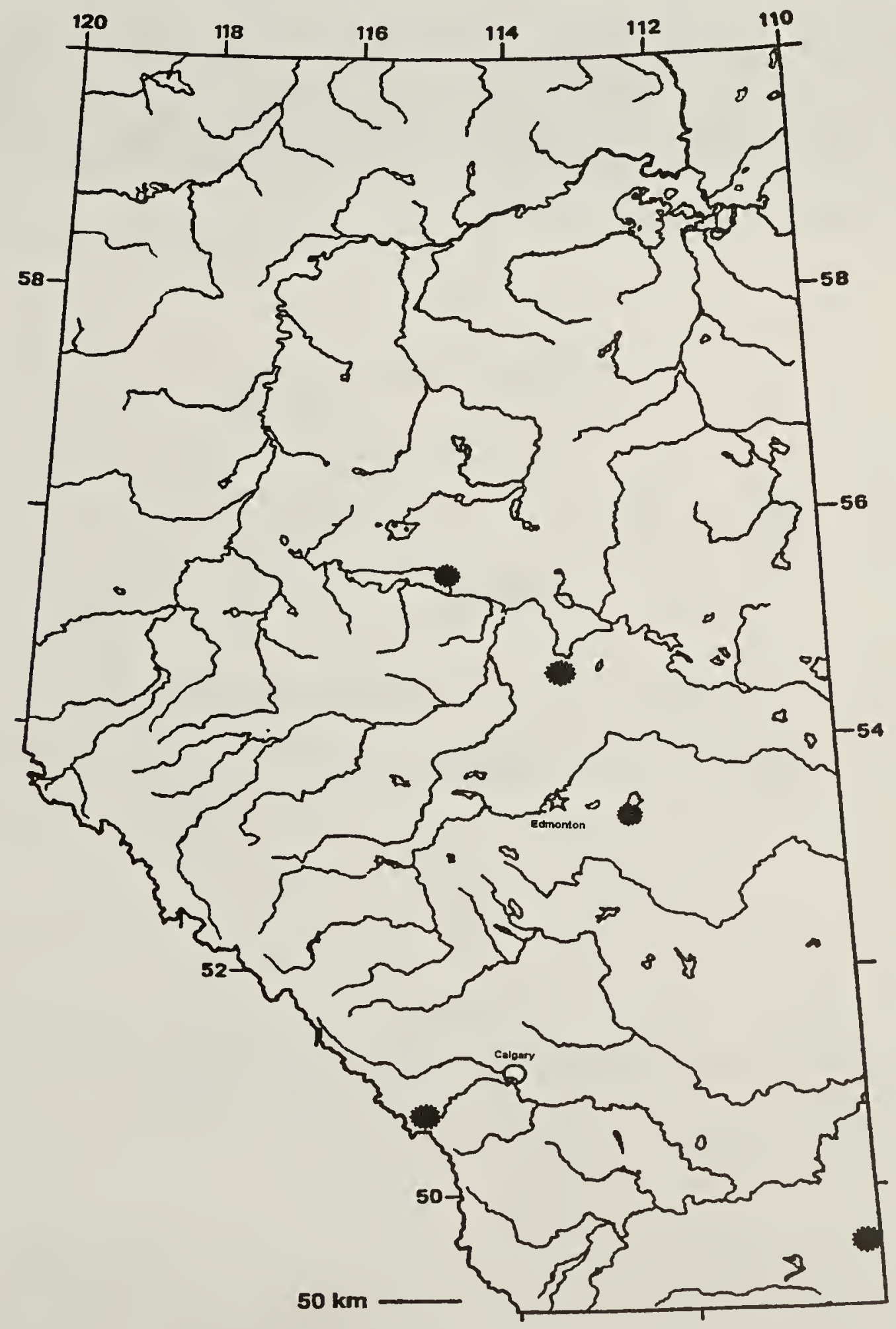


Drift fences are commonly used to inventory amphibian communities. ${ }^{2} \mathrm{~A}$ variety of fence materials have been used including plastic, aluminum, galvanized hardware cloth or silt fencing. ${ }^{1} \quad$ Each new monitoring pond site was surrounded by a silt fencing and pitfall traps ( $11 / 2$ coffee cans deep) to allow capture of animals moving toward or away from the site. Beaverhill had the plastic fencing replaced with silt fencing, as it was heavily damaged by coyotes and beavers, while Lesser Slave and Meanook simply had the plastic fencing repaired. Fencing completely surrounded each pond, and pairs of pitfall traps were placed every $10 \mathrm{~m}$ along each side of this fence (Figure 2). At Beaverhill nine arrays of fencing (10 $\mathrm{m}$ each) were set in three habitat types along a small lake.

Figure 2: Diagram showing fencing and pitfall trap set-up.
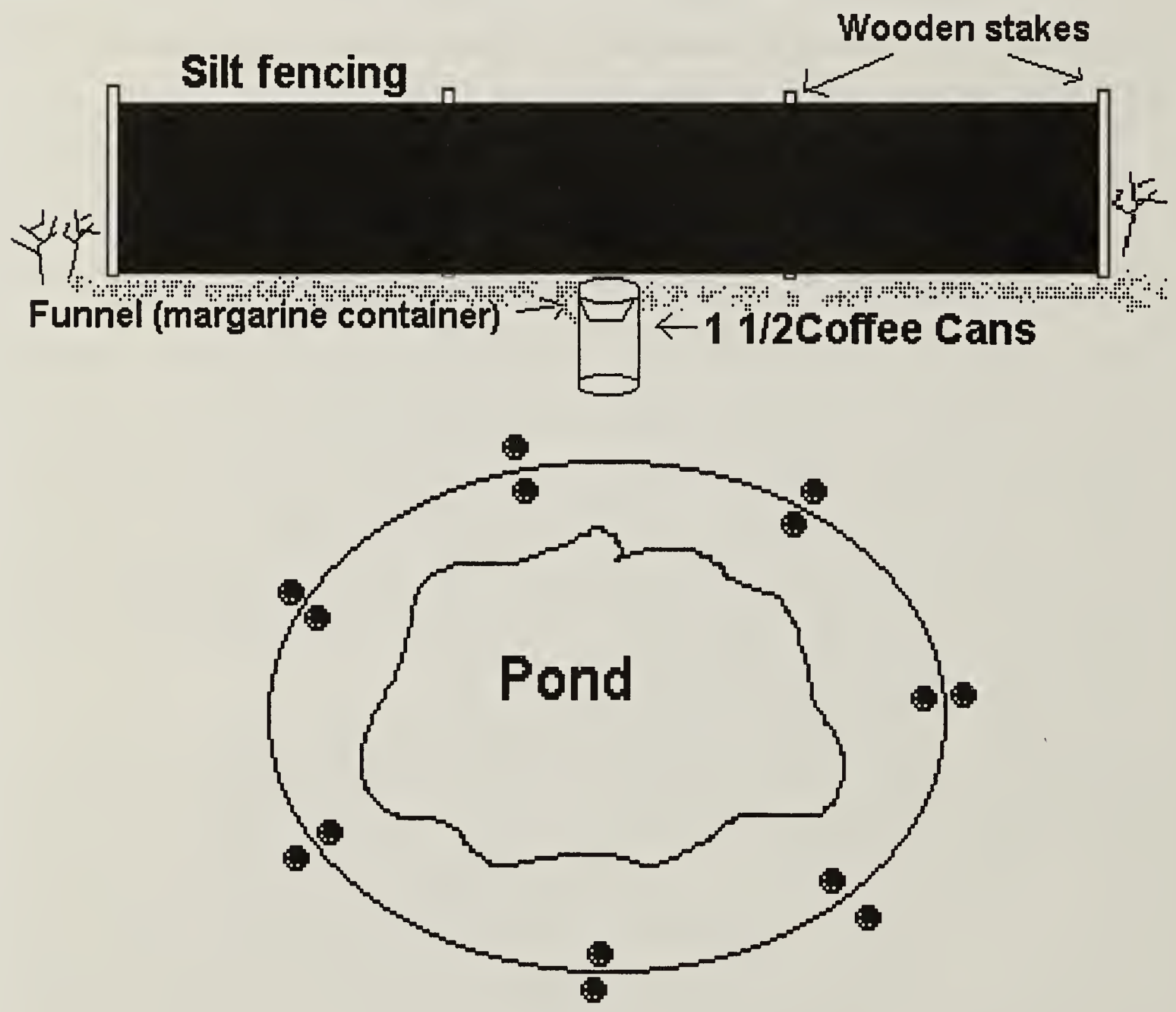

Beaverhill, Lesser Slave, and Kananaskis were surveyed for three consecutive weeks in the spring, intermittently in the summer, and three consecutive weeks later in July and August. Cypress Hills and Meanook were only surveyed in July and August. When sites were not in operatioon, plastic tops were placed on top of the coffee cans and the fencing was opened up to allow amphibians to move freely to and from the pond.

\section{Results}

In 1998, over 1200 amphibians were captured at the five sites, representing eight species: 
Long-toed Salamander (Ambystoma macrodactylum)

Columbia Spotted Frog (Rana luteiventris)

Tiger Salamander (Ambystoma tigrinum)

Northern Leopard Frog (Rana pipiens)

Boreal Chorus Frog (Pseudacris maculata)

Boreal Toad (Bufo boreas)

Wood Frog (Rana sylvatica)

Canadian Toad (Bufo hemiophrys)

Wood frogs and boreal chorus frogs were the most common species while the Canadian toad was the least common amphibian captured (Table 2). Captures varied in different ecoregions. Wood frogs were caught at every site but Cypress Hills. Spotted frogs and long-toed salamanders were only captured at Kananaskis. No great plains

toads or plains spadefoots were caught at any of the sites. More tiger salamanders were captured at Beaverhill in 1997 than in 1998. Boreal toad captures at Meanook and Lesser Slave Lake were much higher in 1998, while wood frog captures dropped at Meanook (Table 3).

Table 2: Numbers of each species captured at RANA sites in 1998.

\begin{tabular}{llllllllll}
\hline Study Site & LTSA & TISA & BCFR & WOFR & CSFR & NLFR & BOTO & CATO & TOTAL \\
\hline $\begin{array}{l}\text { Beaverhill } \\
\text { Lake }\end{array}$ & 0 & 1 & 17 & 182 & 0 & 0 & 0 & 0 & 200 \\
Cypress Hills & 0 & 31 & 2 & 0 & 0 & 5 & 0 & 0 & 38 \\
Kananaskis & 186 & 0 & 0 & 61 & 7 & 0 & 33 & 0 & 287 \\
$\begin{array}{l}\text { Lesser Slave } \\
\text { Lake }\end{array}$ & 0 & 0 & 5 & 33 & 0 & 0 & 23 & 1 & 62 \\
Meanook & 0 & 0 & 4 & 277 & 0 & 0 & 343 & 0 & 624 \\
\hline TOTAL & 186 & 32 & 28 & 553 & 7 & 5 & 399 & 1 & 1211 \\
\hline
\end{tabular}

Table 3: Numbers of each species captured at RANA sites in 1997.

\begin{tabular}{lllllll}
\hline Study Site & TISA & BCFR & WOFR & BOTO & CATO & TOTAL \\
\hline $\begin{array}{l}\text { Beaverhill } \\
\text { Lake }\end{array}$ & 21 & 0 & 0 & 0 & 0 & 21 \\
$\begin{array}{l}\text { Lesser Slave } \\
\begin{array}{l}\text { Lake } \\
\text { Meanook }\end{array}\end{array}$ & 0 & 10 & 73 & 7 & 0 & 90 \\
\hline TOTAL & 21 & 14 & 266 & 10 & 0 & 311 \\
\hline
\end{tabular}

\section{Public Education}

1265 people visited RANA sites in 1998 (Table 4), compared to 386 in
1997. Lesser Slave Lake, Beaverhill, and Meanook more than doubled the number of people visiting the sites. 


\section{Number of People}

Location

\begin{tabular}{lll}
\hline & 1997 & 1998 \\
\hline Beaverhill Lake & 50 & 125 \\
Cypress Hills & - & 150 \\
Kananaskis & - & 359 \\
Lesser Slave Lake & 326 & 611 \\
Meanook & 10 & 20 \\
\hline TOTAL & 386 & 1265 \\
\hline
\end{tabular}

\section{Acknowledgements}

Funding and in-kind support from the following agencies is greatly appreciated: Alberta Conservation Association, Alberta Environmental Protection - Fisheries and Wildlife Management Division, University of Alberta Department of Biological Sciences, Alberta Sport, Recreation, Parks and Wildlife Foundation, Student Career Placement Program (Human Resources Canada), Beaverhill Bird Observatory, Lesser Slave Lake Provincial Park, University of Calgary Kananaskis Field Station, Cypress Hills Provincial Park, WISEST - Women in Scholarship, Engineering, Science, and Technology.

I would also like to acknowledge the RANA field coordinators for their hard work: Beaverhill Lake - Christine Rice, Shannon Quinn, Lisa Burt, Cypress Hills - Jon Hornung, Kananaskis - Jennifer Dober, Lesser Slave Lake - Andrew Yeo, Meanook - Emma Crawford.
Research input and support was appreciated from the following individuals: Brian Eaton, Cindy Paszkowski, Steve Brechtel, Bruce Treichel, Kris Kendell, and Jeff Adamyk. Finally special thanks to all the volunteers that helped at each of the study sites.

1. ENGE, K.M. 1997. Use of silt fencing and funnel traps for drift fences. Herpetological Review 28: 30-31.

2. HEYER, W.R., M.A. DONNELLY, R.W. MCDIARMID, L.A.C. HAYEK, and M.S. FOSTER. 1994. Measuring and monitoring biological diversity: standard methods for amphibians. Smithsonian Institution Press, Washington. 364 pp.

3. PECHMANN, J.H.K. and H.M. WILBUR. 1994. Putting declining amphibian populations in perspective: natural fluctuations and human impacts. Herpetologica 50: 65-84. 